13. Алексеев Ю.В. Тяжелые металлы в почвах и растениях. Л.: Агропромиздат, 1987. $142 \mathrm{c}$.

14. Методические указания по определению тяжелых металлов в почвах сельхозугодий и продукции растениеводства. Центральный институт агрохимического обслуживания сельского хозяйства (ЦИНАО). М., 1989. 63 с.

15. Методические указания по определению тяжелых металлов в почвах сельхозугодий и продукции растениеводства. Изд. 2-е, переработанное и дополненное. М.: ЦИНАО, 1992. $61 \mathrm{c.}$

16. Михалева О.С., Тюрин А.Н. Морфологическое строение почвенного профиля заповедных территорий (на примере Государственного природного заповедника «Оренбургский»): колл. монография. СПб.: РГПУ им. А.И. Герцена, 2013. С. 243-246.

17. Тюрин А.Н. Характеристика почвенного профиля чернозема южного на участке Айтуарской степи Государственного природного заповедника «Ope- нбургский» // Наука и образование в XXI веке: сб. науч. тр. по материалам междунар. науч.-практ. конф. 30 сентября 2013 г.: в 34 ч. Ч. 6. Тамбов: ТРОО «Бизнес-Наука-Общество», 2013. С. 144-145.

18. Тюрин А.Н. Черноземы Государственного природного заповедника «Оренбургский» // Объекты природного наследия и экотуризм: мат-лы междунар. науч.-практ. конф., Улан-Удэ - п. Гремячинск, 2527 августа 2014 г. / под общ. ред. проф. М.В. Слипенчука. М.: МГУ, 2014. С. 79-83.

19. Блохин Е.В. Экология почв Оренбургской области: почвенные ресурсы, мониторинг, агроэкологическое районирование. Екатеринбург, 1997. 227 с.

20. Березнёв А.П., Тюрин А.Н. Экологическая реабилитация чернозема южного Айтуарской степи в условиях заповедного режима // Степи Северной Евразии: мат-лы VII междунар. симпозиума / под науч. ред. чл.-корр. РАН А.А. Чибилёва. Оренбург: ИС УрО РАН, Печатный дом «Димур», 2015. С. 859-862.

\title{
RESTORATION OF SOIL FERTILITY OF THE SOUTHERN CHERNOZEM IN CONDITIONS OF THE RESERVE REGIME OF THE ORENBURG STATE NATURE RESERVE
}

(C) 2018

Tyurin Alexander Nikolaevich, candidate of geographical sciences, associate professor of Geography and Geographical Sciences Methods of Teaching Department Orenburg State Pedagogical University (Orenburg, Russian Federation)

Abstract. This paper presents a comparative-temporal ecological characterization of the southern chernozem under the regime of the Aituar steppe site command of the Orenburg State Nature Reserve. The degree of ecological rehabilitation of chernozems in specially protected natural areas is shown. Quantitative data are provided on the supply of soil with nitrogen, phosphorus and potassium, and the content of heavy metals in the soil. Determination of the content of heavy metals and trace elements in soil samples (according to the method of Krupsky and Aleksandrova in the modification of the Central Institute of Agrochemical Services for Agriculture) was conducted in accordance with GOST 50683-94. The determination of mobile compounds of phosphorus and potassium was carried out by the method of Machigin (GOST-26205-91), organic matter by the Tyurin method (GOST 26213-9), alkaline hydrolyzable nitrogen by Kornfield. The paper presents the results of a comparison of agrochemical and ecology-toxicological studies of southern chernozem in 1996-2016. The main morphogenetic characteristics of the soil profile of the chernozem of the southern carbonate low-humus low-mass medium loamy are given. Data of morphological, physical and agrochemical properties of soils were subjected to mathematical and statistical treatment. This allowed the authors to determine morphological parameters, qualitative and quantitative characteristics of the soil and their variation within the elementary soil areas, depending on the position in the landscape and the nature of use. The data obtained indicate a positive dynamics in the provision of soil with humus and elements of mineral nutrition of plants, as well as a significant reduction in the content of heavy metals throughout the soil profile. Thus, we can talk about the natural restoration of soil fertility in conditions of a protected regime in specially protected natural areas.

Keywords: soil; southern chernozem; soil fertility; Aituar steppe; state natural reserve «Orenburg»; ecological rehabilitation; heavy metals; agrochemical and ecology-toxicological studies; morphological and physical properties of soil; protected regime.

УДК 574.52

Статья поступила в редакцию 21.03.2018

\section{СОДЕРЖАНИЕ ТЯЖЕЛЫХ МЕТАЛЛОВ В ТКАНЯХ И ОРГАНАХ РЫБ РЕКИ БЕЛАЯ}

\author{
Хуснутдинова Лилия Ралифовна, магистрант кафедры биологии и экологии \\ Исхакова Айгуль Тимербаевна, кандидат биологических наук, доцент, \\ заведующий кафедрой биологии и экологии \\ Бирский филиал Башкирского государственного университета \\ (2. Бирск, республика Башкортостан, Российская Федерация)
}

Аннотащия. В данной статье рассматриваются содержание и особенности накопления тяжелых металлов в органах и тканях рыб реки Белая, выловленных в районе городов Бирск и Уфа республики Башкортостан. 
Для определения содержания ионов железа, меди, кадмия, свинца были исследованы мышцы, печень и кровь карпа обыкновенного (Cyprinus carpio L.) и густеры обыкновенной (Blicca bjoerkna L.). Оба вида относятся к растительноядным рыбам, но предпочитают разные места обитания: карп является придонной рыбой, а густера обитает в толще воды. Выбор изученных видов рыб связан с широкой распространенностью их в данной реке. Исследования показали, что биогенные элементы (железо, медь) интенсивнее аккумулируются в крови рыб, а в случае других изученных тяжелых металлов (свинец и кадмий) аккумулирующим органом является печень. Анализ тканей и органов рыб на наличие ионов тяжелых металлов проводился методом атомно-абсорбционной спектроскопии в лаборатории экологического мониторинга физико-химических загрязнений окружающей среды Бирского филиала Башкирского государственного университета (г. Бирск). Полученные нами результаты могут служить основой для мониторинга экологического состояния воды реки и обитающих там гидробионтов.

Ключевые слова: предельно допустимая концентрация; река Белая; экологический мониторинг; органы и ткани рыб; степень накопления; город Бирск; город Уфа; республика Башкортостан; биоаккумуляция тяжелых металлов; физико-химический анализ воды; гидробионты; ионы железа; ионы кадмия; ионы свинца; ионы меди.

\section{Введение}

Во многих промышленных странах, включая Россию, в связи с продолжающимся загрязнением большинства водных объектов проблема накопления тяжелых металлов в тканях и органах рыб остается весьма актуальной [1].

Соединения тяжелых металлов - это плохо разлагающиеся и хорошо аккумулирующиеся в живых организмах вещества. Их полезные и вредные свойства весьма противоречивы: с одной стороны, они входят в состав различных гормонов, ферментов и других соединений, необходимых для функционирования организма, и участвуют в различных реакциях, управляя его жизнедеятельностью [2]. Однако с другой стороны, приобретая разные конфигурации и соединяясь с различными веществами, они создают изомеры, которые негативно влияют на организм и становятся губительной глобальной проблемой всего человечества. Тяжелые металлы загрязняют все среды жизни, что сказывается на биологическом разнообразии биотопов [3]. Многие тяжелые металлы в огромных количествах поглощаются пресноводными бактериями. В результате этого образуются металлоорганические соединения, гораздо более ядовитые, чем сами металлы. В первую очередь от таких загрязнений страдают гидробионты - жители водной экосистемы [4]. Главной и не контролируемой особенностью тяжелых металлов является то, что они аккумулируются в живых организмах. Согласно правилу биологического усиления, они могут передвигаться вверх по пищевым сетям, увеличивая свою токсичность и вызывая заболевания и гибель растений и рыб [5].

Данная проблема актуальна и в республике Башкортостан. Ведущей водной артерией республики Башкортостан является река Белая. Она славится огромными запасами промысловых видов рыб, среди которых встречаются такие виды как голец, карп, щука, густера, пескарь, окунь. К наиболее часто встречающимся в улове рыбам относятся карп обыкновенный, или сазан, и густера обыкновенная.

Река Белая с давних пор испытывает на себе антропогенную нагрузку и с увеличением количества предприятий в городах, расположенных на берегу этой реки, данная нагрузка растет, что отражается на состоянии ихтиофауны. Наличие тяжелых металлов в водной среде приводит к накоплению тяжелых металлов в различных органах и тканях гидробионтов, в частности рыбах. Согласно данным Л.И. Законновой (2008), это ведет к снижению не только разнообразия рыб, но и ухудшению их физиолого-биохими- ческих свойств, что, несомненно, влияет на вкусовые качества мяса рыб, выловленных в реках [6].

Избыток тяжелых металлов оказывает отрицательное влияние на обмен веществ водных организмов, способен вызывать уродства, подавлять рост и делать рыб более восприимчивыми к разнообразным болезням. Физиологическая роль многих тяжелых металлов ещё до конца не изучена, поэтому в настоящее время нет единого подхода к количественной оценке предельно допустимого их содержания в организме разных видов рыб. В исследованиях И.Л. Головановой (2008) отмечено, что в результате отравления тяжелыми металлами нарушается проницаемость оболочек клеток крови [7]. Образующиеся при попадании в организм стойкие комплексы с тяжелыми металлами способны откладываться в тканях и органах, избирательно накапливаясь и отравляя организм.

Изучение накопления тяжелых металлов в органах рыб реки Белая начато сравнительно недавно и обусловлено необходимостью получения данных о влиянии загрязнения воды на организм и отдельные органы гидробионтов. В связи с этим целью нашего исследования явилось изучение содержания и распределения тяжелых металлов (железо, медь, кадмий, свинец) в органах доминантных видов рыб реки Белая в районе г. Бирск и г. Уфа республики Башкортостан.

\section{Методы исследования}

Для изучения физико-химического состава воды были отобраны пробы из реки Белая в районе городов Бирск и Уфа республики Башкортостан. Анализы воды выполнялись в лаборатории экологического мониторинга физико-химических загрязнений окружающей среды Бирского филиала БашГУ (г. Бирск) с использованием метода атомно-абсорбционной спектрометрии (ААС). Отбор проб воды проводился согласно ГОСТ 31861-2012 «Вода. Общие требования к отбору проб» [8].

Для исследования содержания ионов железа, меди, кадмия и свинца были отобраны наиболее часто встречающиеся в реке Белая виды рыб: карп обыкновенный (Cyprinus carpio L.) и густера обыкновенная (Blicca bjoerkna L.). Были изучены образцы тканей и органов (мышцы, печень и кровь) рыб. Кровь для анализа брали прижизненно из хвостовой вены рыб. Количественный анализ образцов на содержание тяжелых металлов проводили на спектрометре «КВАНТ-Z.-ЭТА» методом ААС после предварительной влажной минерализации проб в концентрированной азотной кислоте с последующим термическим разложением. 
Хуснутдинова Л.Р., Исхакова А.Т

\section{Результаты исследования} и их обсуждение

Проведенное исследование показало, что в воде реки Белая содержание ионов железа превышает предельно допустимую концентрацию в 3-5 раз в районе городов Бирск и Уфа (табл. 1). По мнению исследователей Р.Ф. Абдрахманова и В.Г. Попова (2013), источником ионов железа в воде являются горные породы. Насыщенными ионами железа оказываются подземные воды в толщах юрских глин. В глинах много пирита $\left(\mathrm{FeS}_{2}\right)$, и ионы железа из него относительно легко переходят в воду [9].

Таблица 1 - Содержание тяжелых металлов в воде реки Белая

\begin{tabular}{|c|c|c|c|}
\hline \multirow{2}{*}{$\begin{array}{c}\text { Пока- } \\
\text { за- } \\
\text { тель, } \\
\text { мг/дм }\end{array}$} & \multicolumn{2}{|c|}{$\begin{array}{c}\text { Гидрохимические } \\
\text { показатели }\end{array}$} & $\begin{array}{c}\text { ПГК } \\
\text { мг/дм } \\
\text { (ры- } \\
\text { бохозяй- } \\
\text { ственная) }\end{array}$ \\
\hline $\mathrm{Fe}$ & $0,2700 \pm 0,025$ & $0,4800 \pm 0,019$ & 0,100 \\
\hline $\mathrm{Cu}$ & $0,0040 \pm 0,002$ & $0,0030 \pm 0,001$ & 0,001 \\
\hline $\mathrm{Cd}$ & $0,0020 \pm 0,000$ & $0,0060 \pm 0,001$ & 0,005 \\
\hline $\mathrm{Pb}$ & $0,0095 \pm 0,005^{\wedge}$ & $0,0140 \pm 0,005$ & 0,006 \\
\hline
\end{tabular}

Примечание. ${ }^{\wedge}$ - достоверность различий в содержании тяжелых металлов в воде реки Белая в районе г. Бирск и г. Уфа.

Также значительное количество ионов железа в поверхностные воды поступает с сельскохозяйственными стоками, что, по данным А.Г. Москвина (1999), является одной из основных причин превышения ПДК по указанному показателю [10]. Развитое промышленное производство в городах республики Башкортостан, расположенных на берегу реки Белая выше по течению г. Уфа, увеличивает антропогенную нагрузку на водоток. Это находит свое отражение в содержании свинца и кадмия. Так, в воде реки Белая в районе г. Уфа концентрация свинца и кадмия больше, чем в районе г. Бирск. Известно, что железо способно вытеснять медь из соединений и осаждать ее. Данный факт, вероятно, имеет место в результатах нашего исследования: концентрация ионов меди в воде реки Белая в районе г. Бирск больше, чем в районе г. Уфа.

Анализ данных показал, что концентрация металлов в органах рыб выше, чем их уровень в воде, что обусловлено способностью данных представителей ихтиофауны к биоаккумуляции. Содержание различных тяжелых металлов в мышечной ткани, печени и крови рыб разных видов различно (табл. 2).

Содержание железа превышено во всех изученных органах у обоих видов рыб, кроме мышечной ткани густеры, обитающей в р. Белая в районе г. Бирск. Высокий уровень железа, вероятно, связан с большой ролью этого элемента в дыхательной и кроветворной системах. Ионы железа необходимы для жизнедеятельности организма, являются фундаментальным фактором для многих процессов, связанных с переносом кислорода, участвуют в синтезе порфирита в гемоглобине и миоглобине [11]. У карпа содержание ионов железа во всех исследованных органах больше, чем у густеры, что, вероятно, связано с придонным образом жизни. Максимальные концентрации железа обнаружены в крови как карпа, так и густеры.

Функционально железо является антагонистом меди. Так, например, железо принимает участие в образовании клеток крови, а медь ингибирует ферменты, определяющие синтез гема и тем самым нарушает синтез клеток крови. Медь играет большую роль в ферментативной деятельности организма и поступает преимущественно с пищей. У всех видов рыб отмечается большая концентрация меди в организме по сравнению с другими тяжелыми металлами. Высокий уровень меди, возможно, связан с большим количеством ее в воде. Медь может попадать в реку Белая со сточными водами предприятий цветной металлургии, что подтверждается превышением уровня ПДК в воде. В основном медь накапливается в крови рыб, что, скорее всего, связано с биогенностью данного элемента. Содержание меди в мышцах меньше, чем в печени. Интенсивность аккумуляции меди мышцами и кровью у карпа выражена в большей степени, чем у густеры.

Таблица 2 - Содержание тяжелых металлов в организме рыб, обитающих в реке Белая

\begin{tabular}{|c|c|c|c|c|c|c|c|c|}
\hline \multirow{2}{*}{ Вид } & \multirow{2}{*}{$\begin{array}{c}\text { Пока- } \\
\text { за- } \\
\text { тель }\end{array}$} & \multirow{2}{*}{$\begin{array}{l}\text { ПДУ, } \\
\text { мг/кг }\end{array}$} & \multicolumn{2}{|c|}{$\begin{array}{c}\text { Содержание тяжелых ме- } \\
\text { таллов в мышцах рыб, мг/кг }\end{array}$} & \multicolumn{2}{|c|}{$\begin{array}{c}\text { Содержание тяжелых метал- } \\
\text { лов в печени рыб, мг/кг }\end{array}$} & \multicolumn{2}{|c|}{$\begin{array}{l}\text { Содержание тяжелых ме- } \\
\text { таллов в крови рыб, мг/кг }\end{array}$} \\
\hline & & & г. Бирск & г. Уфа & г. Бирск & г. Уфа & г. Бирск & г. Уфа \\
\hline \multirow{4}{*}{$\begin{array}{l}\text { Карп } \\
\text { обык- } \\
\text { новен- } \\
\text { ный }\end{array}$} & $\mathrm{Fe}$ & 1,2 & 1,7 & 22 & & 2,1 & * & $5,3 \pm$ \\
\hline & $\mathrm{Cu}$ & 10,0 & $1,3 \pm 0,13^{\wedge Z}$ & $3,1 \pm 0$ & $12,2 \pm 0,5^{\mathrm{X}}$ & $12,9 \pm$ & $15,3 \pm 0,6 * \mathrm{Z}$ & 18 , \\
\hline & $\mathrm{Cd}$ & 0,2 & $0,02 \pm 0,009^{\wedge}$ & $0,04 \pm 0,007^{\wedge \mathrm{Z}}$ & $0,11 \pm 0,023^{\mathrm{XZ}}$ & $0,2 \pm 0,042^{\mathrm{XZ}}$ & $\begin{array}{c}0,002 \pm \\
\pm 0,0003^{Z}\end{array}$ & $\begin{array}{c}0,06 \pm \\
\pm 0,009^{\mathrm{YZ}}\end{array}$ \\
\hline & $\mathrm{Pb}$ & 1,0 & $0,01 \pm 0,002^{\wedge}$ & $0,3 \pm 0,09^{\wedge} \mathrm{Y}$ & $0,09 \pm 0,025^{Z}$ & $1,5 \pm 0,27^{\mathrm{Y}}$ & $0,05 \pm 0,014 * Z$ & $1,2 \pm 0,24 * Y$ \\
\hline \multirow{4}{*}{$\begin{array}{l}\text { Густера } \\
\text { обык- } \\
\text { новен- } \\
\text { ная }\end{array}$} & $\mathrm{Fe}$ & 1,2 & $1 \pm$ & $2 \pm$ & $1,7=$ & $2 \pm 0,321^{x}$ & $2,4 \pm 0,298^{*}$ & $2,9 \pm 0,336^{*}$ \\
\hline & $\mathrm{Cu}$ & 10,0 & $3,1 \pm 0,467^{\wedge}$ & $4,2 \pm 0,45^{\wedge}$ & $10,9 \pm 0,485$ & $14,7 \pm 0,746^{\mathrm{Y}}$ & $12 \pm 0,91^{*}$ & $\begin{array}{c}16,4 \pm \\
\pm 1,342 * \mathrm{Y}\end{array}$ \\
\hline & $\mathrm{Cd}$ & 0,2 & $0,04 \pm 0,01^{\wedge}$ & $0,12 \pm 0,025^{\mathrm{Y}}$ & $0,007 \pm 0,001^{\mathrm{X}}$ & $0,15 \pm 0,021^{\mathrm{XY}}$ & $0,1 \pm 0,019^{*}$ & $0,3 \pm 0,054^{\mathrm{Y}}$ \\
\hline & $\mathrm{Pb}$ & 1,0 & $0,01 \pm 0,001^{\wedge}$ & $0,5 \pm 0,114^{\wedge} \mathrm{Y}$ & $0,02 \pm 0,002^{\mathrm{X}}$ & $1,7 \pm 0,114^{\mathrm{XY}}$ & $0,01 \pm 0,003$ & $0,81 \pm 0,127^{Y}$ \\
\hline
\end{tabular}

Примечание. ${ }^{\wedge}$ - достоверность различий в содержании тяжелых металлов в мышцах и печени рыб одного вида, обитающих в одной местности; *-достоверность различий в содержании тяжелых металлов в крови и мышцах рыб одного вида, обитающих в одной местности; ${ }^{\mathrm{X}}$ - достоверность различий в содержанием тяжелых металлов в печени и крови рыб одного вида, обитающих в одной местности; ${ }^{Y}$ - достоверность различий в содержании тяжелых металлов в органах рыб одного вида, обитающих в разной местности; ${ }^{\mathrm{Z}}$ - достоверность различий в содержании тяжелых металлов в органах рыб разных видов, обитающих в одной местности. 
Содержание ионов кадмия в органах обследованных рыб не превышает ПДУ. Исключение составляет густера, обитающая в реке Белая в районе г. Уфа, в крови которой обнаружено превышение ПДУ по кадмию на $50 \%$. Активнее аккумулируют кадмий рыбы, обитающие в реке Белая в районе г. Уфа, чем в районе г. Бирск. Максимальные концентрации кадмия выявлены у карпа в печени, а у густеры - в крови. Кадмий является опасным и не биогенным металлом, в чистом виде в природе не встречается. Согласно литературным данным для кадмия характерна аккумуляция в тканях почек. Во многих случаях кадмий способен замещать цинк в цинксодержащих ферментах, что также может приводить к его накоплению в печени [12].

Ионы свинца больше всего накапливаются в печени, что может быть обусловлено как внешними (пищевой путь поступления), так и внутренними (специфической функцией печени, особым аминокислотным составом ее белков либо особыми условиями существования данных металлов в тканях печени, способствующими их накоплению) факторами [13]. Результаты нашего исследования согласуются с литературными данными. Максимальное содержание свинца в организме карпа и густеры обнаруживается в тканях печени. Анализ результатов исследования показал, что у рыб, выловленных из загрязненного участка реки (район г. Уфа), обнаруживается наиболее высокая концентрация свинца в мышцах, печени и крови.

Повышенное содержание большинства исследованных тяжелых металлов в органах придонной рыбы реки Белая, вероятно, связано с высоким уровнем их накопления не только в воде, но и в пище, и в донных отложениях водотока [14].

\section{Заключение}

Анализ результатов исследования по содержанию тяжелых металлов в рыбах реки Белая в районе городов Бирск и Уфа республики Башкортостан свидетельствует о сложном характере накопления этих элементов в организме рыб (в мышцах, тканях печени, крови), о зависимости этого процесса от условий обитания и образа жизни рыб. Некоторые тяжелые металлы накапливаются, как правило, в больших концентрациях в печени растительноядных рыб [15]. Содержание высоких концентраций тяжелых металлов в печени рыб объясняется функциональной составляющей этого органа, что не противоречит литературным данным [16; 17]. Интенсивность поступления и избыточный уровень тяжелых металлов в органах рыб также зависит от степени загрязненности среды обитания: рыбы экосистемы реки в районе г. Уфа имеют высокие показатели загрязненности тяжелыми металлами. Способность аккумулировать тяжелые металлы в органах и тканях рыб неодинакова. Так, например, печень аккумулирует свинец активнее, чем кровь, а у крови аккумуляционная способность выше, чем у мышц. Для железа и меди повышенной биоаккумуляцией обладает кровь рыб.

Таким образом, анализ содержания железа, меди, кадмия, свинца и выявленные закономерности их накопления в тканях и органах исследуемых рыб согласуются с биохимической ролью металлов в жизнедеятельности организма. Анализ содержания и распределения тяжелых металлов в тканях рыб позволяет сделать вывод о том, что исследуемые виды рыб реки Белая содержат превышающий ПДУ по большинству исследованных тяжелых металлов. Употребление в пищу таких рыб может привести к накоплению тяжелых металлов в организме человека и нарушить нормальное функционирование организма.

\section{Список литературы:}

1. Воскресенская О.Л., Скочилова Е.А. Организм и среда: факториальная экология. Йошкар-Ола. 2005. $175 \mathrm{c}$.

2. Петров К.М. Экология и культура // Экологическая культура. 2011. № 3. С. 36.

3. Островская Е.В., Бреховских В.Ф., Волкова 3.В., Монахов С.К., Курапов А.А., Кочарян А.Г. Тяжелые металлы в системе «дельта Волги Северный Каспий» // Юг России: экология, развитие. 2008. № 4. С. $133-139$.

4. Попов П.А., Трифонова О.В. Содержание и характер накопления металлов в рыбах // Сибирский экологический журнал. 2007. № 6. С. 961-967.

5. Барабанова О.А., Безкоровайная И.Н., Бухарова Е.Б. Экология: курс лекций. Красноярск. 2010. $325 \mathrm{c}$

6. Законнова Л.И. Технология формирования генетически отдаленных линий карпа на основе местного беспородного стада. Белово: ООО «Канцлер», 2008. $118 \mathrm{c}$.

7. Голованова И.Л. Влияние тяжелых металлов на физиолого-биохимический статус рыб и водных беспозвоночных // Биология внутренних вод. 2008. № 1. C. $99-108$.

8. ГОСТ 31861-2012. Вода. Общие требования к отбору проб. М.: Стандартинформ, 2013.

9. Абдрахманов Р.Ф., Попов В.Г. Ионообменная концепция в генетической гидрохимии. Уфа: Гилем, 2013. $357 \mathrm{c}$.

10. Москвин А.Г. Экология водоемов России. Рязань: Школа-Пресс, 1999. 134 с.

11. Мудрый И.В. Влияние химического загрязнения почвы на здоровье населения // Гигиена и санитария. 2008. № 4. С. 32-37.

12. Колесников С.И., Казеев К.Ш., Вальков В.Ф. Экологические последствия загрязнения почв тяжелыми металлами: монография. Ростов-на-Дону: Издво СКНЦ ВШ, 2000. 232 с.

13. Акимова Т.А., Кузьмин А.П., Хаскин В.В. Экология. Природа. Человек. Техника. М.: ЮНИТИДАНА, 2001. $343 \mathrm{c}$.

14. Попов П.А. Оценка экологического состояния водоемов методами ихтиоиндикации. Новосибирск: Изд-во НГУ, 2002. 270 с.

15. Смирнова Е.В., Карамушко О.В. Пространственное распределение и некоторые черты биологии чернобрюхого липариса Liparis, 1984 в Карском море // Вестник Кольского научного центра РАН. 2015. № 1 (20). C. 78-84.

16. Сибагатуллина А.М., Мазуркин П.М. Измерение загрязненности речной воды. М.: Изд-во «Академия естествознания», 2009. $216 \mathrm{c.}$

17. Авалиани С.Л., Ревич Б.А., Захаров В.М. Мониторинг здоровья человека и здоровья среды. Региональная экологическая политика. Центр экологической политики России. М.: Наука, 2001. 76 с. 


\title{
HEAVY METALS CONTENT IN ORGANS AND TISSUES OF FISH FROM THE BELAYA RIVER
}

(C) 2018

\author{
Khusnutdinova Lilia Ralifovna, master student of Biology and Ecology Department \\ Iskhakova Aigul Timerbaevna, candidate of biological sciences, associate professor, \\ head of Biology and Ecology Department \\ Birsk branch of Bashkir State University (Birsk, Republic of Bashkortostan, Russian Federation)
}

Abstract. This paper considers the content and peculiarities of heavy metals accumulation in the organs and tissues of fish from the Belaya River, caught in the cities of Birsk and Ufa in the Republic of Bashkortostan. To determine the content of iron, copper, cadmium and lead ions, the muscles, liver and blood of the common carp (Cyprinus carpio L.) and common bream (Blicca bjoerkna L.) were examined. Both species belong to herbivorous fish, but they prefer different habitats: carp is a ground fish, and the bream lives in the water column. The choice of fish species under study is related to their wide distribution in this river. Studies have shown that biogenic elements (iron, copper) are better accumulated in the fish blood, and for the other heavy metals (lead, cadmium) studied, the accumulating organ is the liver. Analysis of tissues and organs for the presence of heavy metal ions was carried out by atomic absorption spectroscopy in the laboratory of environmental monitoring of physico-chemical environment contamination in the Birsk branch of the Bashkir State University (Birsk). The results obtained can serve as a basis for monitoring the ecological state of the river water and the hydrobionts living there.

Keywords: maximum permissible concentration; Belaya River; ecological monitoring; organs and tissues of fish; degree of accumulation; Birsk city; Ufa city; heavy metals bioaccumulation; Republic of Bashkortostan; physicochemical analysis of water; hydrobionts; iron ions; cadmium ions; lead ions; copper ions.

УДК 547.3+504.75

Статья поступила в редакцию 18.04.2018

\section{ЭКОЛОГО-СОЦИАЛЬНЫЕ ФАКТОРЫ РИСКА В ФОРМИРОВАНИИ ЗДОРОВОГО ОБРАЗА ЖИЗНИ И ИХ ЗНАЧИМОСТЬ ДЛЯ СТУДЕНЧЕСКОЙ МОЛОДЕЖИ}

(C) 2018

Швечихина Юлия Владимировна, аспирант кафедры экологии, ботаники и охраны природы Кавеленова Людмила Михайловна, доктор биологических наук, профессор, заведующий кафедрой экологии, ботаники и охраны природы

Рытов Глеб Львович, кандидат педагогических наук, доцент, декан биологического факультета Самарский наџиональный исследовательский университет имени академика С.П. Королёва (2. Самара, Российская Федеращия)

\footnotetext{
Аннотащия. Сбалансированное социо-демографическое развитие представляет собой составную часть и неотъемлемое условие устойчивого развития социо-эколого-экономических систем на уровнях от регионального до национального. В качестве одного из важных аспектов национальной безопасности страны рассматривается наличие физически и морально здорового, профессионально компетентного населения, формирующего достаточно многочисленные сбалансированные социальные группы. Численность обучающихся в Самарской области студентов на уровне более 100 тыс. чел обеспечивает хорошие возможности для подготовки квалифицированных специалистов, деятельность которых не ограничивается пространством Самарской области. Помимо приобретения профессиональных знаний, умений и навыков, освоения компетенций общего и специального характера, обучающаяся в высшей школе молодежь должна также приобрести глубокую и осознанную мотивацию на формирование здорового образа жизни. В данной статье мы представляем часть уже выполняемого нами комплексного исследования, относящегося к эколого-популяционным основам формирования статуса студенческого здоровья. Важным моментом в этом отношении является, по мнению ВОЗ, борьба с избыточным весом, а одним из сравнительно доступных показателей выступает индекс массы тела. Для модельных выборок студентов Самарского университета, вне связи с направлениями подготовки, распределение по показателю индекса массы тела обнаруживает ситуацию с преобладанием нормального уровня показателя (от 20 до 24) - для юношей и более выраженным преобладанием показателя 20 (нижняя граница нормы) - для девушек. Это представляется неплохой «отправной точкой» для мотивации у студентов формирования здорового образа жизни в дальнейшей перспективе.

Ключевые слова: социально-демографические вызовы; Самарская область; студенческая молодежь; формирование здорового образа жизни; экологические факторы; социальные факторы; психологические факторы; статус здоровья; эколого-популяционные основы формирования здоровья; мотивация здорового образа жизни; индекс массы тела; картина распределения.
}

Важнейшим условием устойчивого развития социо-эколого-экономических систем всех уровней, от регионального до национального, несомненно, является сбалансированное социо-демографическое развитие. Именно наличие достаточно многочисленных социальных групп профессионально компетентного, физически и морально здорового населения служит также основой национальной безопасности страны. В этой связи уместно вспомнить о наличии демографических вызовов, которые эксперты относят к числу главнейших вызовов XXI века, стоящих перед Россией и большинством экономически развитых государств [1]. Эти вызовы обусловлены изменениями в ходе демографических процессов, объединяе- 